\title{
放射光を用いた溶接における凝固・変態過程の その場観察の新手法
}

\author{
小溝 裕一* 寺崎 秀紀* \\ In-situ Observation of Weld Solidification and Transformation Using Synchrotron Radiation \\ Yu-ichi KOMIZO and Hidenori TERASAKI
}

\begin{abstract}
Synopsis : Time-resolved X-ray diffraction system was studied to characterize the unidirectional solidification and the phase transformation during welding. Experimental conditions including wavelength of X-ray, scattering angle, incident angle and time-resolution for analyzing the solidification process in welding were made clear. Furthermore, heating and solidification processes for weld metal of $13 \mathrm{Cr}-9 \mathrm{Ni}$ steel in TIG welding were in-situ analyzed by using the system. The primary phase was identified as delta-phase during solidification with halo pattern for liquid phase, followed by the peritectic reaction with a spot-like diffraction pattern for delta-phase and austenite phase.
\end{abstract}

Key words: in-situ observation; synchrotron radiation; solidification; peritectic reaction; welding; X-ray diffraction.

\section{1. 緒言}

構造物製造上不可欠の技術である溶接においては, 非平 衡加熱, 冷却プロセスに起因する様々な材料利用上の問題 が生じる。例えば, 溶接熱サイクルで加熱, 溶融, 凝固過 程を経て連続冷却される際, 凝固時の偏析に起因する凝固 割れが問題となる場合がある。連続冷却下において, どの 程度の溶質固溶限をもった相が, どういうタイミングで晶 出するかがこの課題のキーポイントであり, 相変態の速度 論的情報が重要となる。

材料の相変態過程を知る方法としては, 熱分析や熱膨張 を測定する方法などが知られているが, これらは $1 \mathrm{~K} / \mathrm{s}$ 程 度の遅い加熱, 冷却速度での変態挙動を測定するものであ り, 溶接部のような急速加熱, 急速冷却 $\left(10-10^{4} \mathrm{~K} / \mathrm{s}\right)$ 過程 に打ける変化は測定できない。しかもこれらは間接的に相 変化を計測する手法である。直接的に相変化を計測するた めには中性子やX線回折が行われるが, 通常の線源では強 度が弱すぎて, 溶接部のような急熱急冷過程をリアルタイ ムで測定できない。

より発展的な解析手法として，90年代後半に放射光を 用いた溶接中の相のその場観察技術が Elmer ら によって 発表された。かれらは溶接中の準定常温度場に打ける純于 タンの相境界のマッピングを $250 \times 500 \mu \mathrm{m}$ という空間分解 能のもとで初めて行った。この研究により液相側の初晶 $\beta$ 相を同定できるなど，相同定手法の大きな発展がなされた。 またElmerらは，低炭素鋼2)，2相ステンレス ${ }^{3)}$ を対象とし
た溶接についても同様の相のマッピングを行い，溶接中の 準定常温度場に扔いて形成される相を同定した。彼らの使 用した実験系においては検出器の感度およびX線源の輝度 の限界により，ひとつの領域の回折を測定するのに 10 秒 の測定時間を要する。そのため測定場所を変えるためには トーチ打よび溶接材料を，固定されたX線照射位置に対し て移動させる必要があり, 測定場所の移動量を小さくしよ うとした場合，すなわち，相変態を，冷却時間の点で高時 間分解能観察するためには実験時間が膨大になるという課 題が残った。Elmerらは, その後 $50 \mathrm{~ms}$ という高時間分解 能計測手法に関する研究4-5)を発表したが, 空間分解能を $730 \mu \mathrm{m} \phi$ に落とし高い時間分解能を確保し，さらに溶融ス ポットをティグアークで形成し冷却させる実験手法を選定 したため, 溶接中の凝固において重要な一方向凝固は再現 されていない。

そこで我々の研究グループでは, より高輝度の放射光, より高感度の検出器を用いた, 溶接トーチ駆動型の in-situ 相同定システムを開発した。これにより，溶接方向に 100 $\mu \mathrm{m}$ の空間分解能（溶接方向と垂直な方向には $2.879 \mathrm{~mm}$ ), $0.02 \mathrm{~s}$ 以下の時間分解能で, 液相から常温組織相までの一 方向凝固過程の相変態を溶接実時間で同定できることが可 能となり, デンドライト群の一方向凝固組織形成を新しい 評価手法で特徴づけした。 


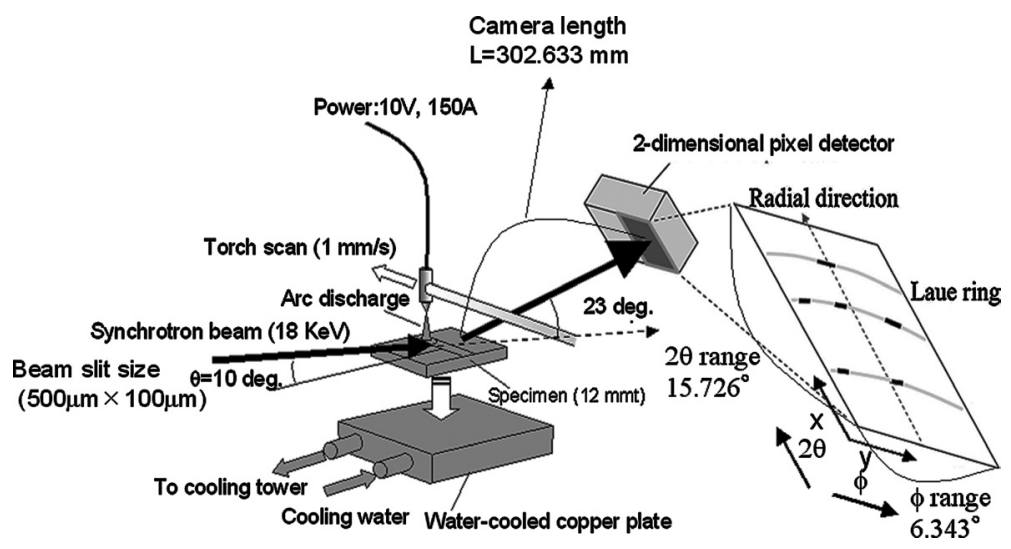

Fig. 1. Schematic drawing of the time-resolved X-ray diffraction system used for in-situ observation.

\section{2. 実験装置}

第3 世代放射光施設である SPring-8内のアンジュレータ ビームライン (BL46XU) を使用した。溶接トーチ駆動型の in-situ相同定システムの模式図を Fig. 1に示す。ビームラ インに設置されている4軸ゴニオ上に水冷銅板を設置する ことで溶接入熱がゴニオメーターに与える影響を排除し た。水冷銅板上に溶接材を設置した。溶接材上面に平行に トーチをステッピングモータによりスライドさせることに より，定速ビードオンプレート溶接をおこなった。アーク 電流, 電圧, 溶接速度はそれぞれ $150 \mathrm{~A}, 10 \mathrm{~V}, 1 \mathrm{~mm} / \mathrm{s}$ と した。溶接の熱履歴は熱電対により測定した。

\section{3. 実験結果および考察}

\section{$3 \cdot 1$ 波長の選定}

入射 $X$ 線および散乱 $X$ 線の単位べクトル $\mathbf{S}_{0}$ と $\mathbf{S}_{1}$ とし， 観察対象の単位格子の単位べクトル $\mathbf{a}, \mathbf{b}, \mathbf{c}$ と反射の指数 $h k l$ とした場合，位相がそろうラウエ条件は次式となる。

$$
\begin{aligned}
& \left(\mathbf{s}_{1}-\mathbf{s}_{0}\right) \cdot \mathbf{a}=h \lambda \\
& \left(\mathbf{s}_{1}-\mathbf{s}_{0}\right) \cdot \mathbf{b}=k \lambda \\
& \left(\mathbf{s}_{1}-\mathbf{s}_{0}\right) \cdot \mathbf{c}=l \lambda
\end{aligned}
$$

ここで, hklは整数。主な測定対象は鉄鋼材料の溶接部で あり，フェライト相およびオーステナイト相が主要な相と なる。格子定数はフェライト相 $2.866 \AA^{6)}$, オーステナイト 相 $3.647 \AA^{6)}$ であるので, 式( 1 )からオングストローム程度 の波長で回折現象が起きる。後述するX線カメラの面積も 小さいことから, 本システムではX線エネルギーとして $18 \mathrm{keV}(\approx 0.68 \AA)$ を選定し，アンジュレータビームを $\operatorname{Si}(111)$ を利用したモノクロメータで単色化し, Fig. 1 に示 すように溶接部に照射した。その入射波長は格子定数 $0.41569162+0.00000097 \mathrm{~nm}$ の粉末 $\mathrm{LaB}_{6}$ 試料を利用し決定 した。

\section{$3 \cdot 2$ 検出角度範囲 $2 \theta, \phi$ および入射角の選定}

X線カメラとして2次元ピクセル検出器を使用した ${ }^{7,8)}$ 。 Fig. 1 中 $x$ 方向のピクセル数は 487, $y$ 方向は 195 であり, ピクセル毎に光子数をカウントすることができる。メカニ カルなシャッターを使用しないこと, 全ピクセル 94965 個 のカウント結果の読み出し速度が $3 \mathrm{~ms}$ であるなどの特徴 により，高時間分解能測定に最適なX線カメラである。さ らに2次元であるため, 一方向凝固するような, 溶接部の 組織変化観察において結晶配向を有する試料も計測するこ とができる。

選定した波長に打けるフェライト相打よびオーステナイ 卜相の最強線の散乱角は $19.32^{\circ} ， 18.58^{\circ}$ となる。さらに， 鉄鋼材料溶接部の組織形成現象において重要な役割を果た す, 酸化物, 窒化物, 硼化物の格子定数が金属に比べ長い ためフェライト, オーステナイトの最強線より低い散乱角 で, 回折することも考慮して, X線カメラを $2 \theta=23^{\circ}$, カメ ラ長を $300 \mathrm{~mm}$ と設定し, ダイレクトビームの位置を検出 器のNo. 240 ピクセルに合わせた場合, 散乱角は 15.20 31.06² と見積もられる。実験においてはダイレクト ビームの測定により，カメラ長および散乱角度は 302.633 mm，14.977 30.703ㄷそれぞれ決定された。さらにカメ ラサイズより $\phi$ 方向(Fig. 1)のレンジは $6.343^{\circ}$ となった。

溶接部における組織変化を時系列に追う実験において, 侵入深さは深いほど溶接部の平均的な情報が得られる。X 線侵入深さは有限の厚さ $t$ の試料からの回折強度と, 試料 厚さが半無限大の值をもつ場合との比 $G$ を 0.99 として試料 中のX線の行路(Fig. 2) を考慮し次式によって求めた ${ }^{9)}$ 。

$$
\int_{0}^{t} \frac{I_{0}}{\sin \gamma} e^{-\mu x(1 / \sin \gamma+1 / \sin \beta)} d x=G \cdot \int_{0}^{\infty} \frac{I_{0}}{\sin \gamma} e^{-\mu x(1 / \sin \gamma+1 / \sin \beta)} d x
$$

ここで, $I_{0}$ は入射 $X$ 線強度, $\gamma, \beta$ は入射ビーム, 回折ビー 厶の試料表面に対する角度である。KEKリポートに記さ れている $17.97 \mathrm{keV}$ の X線エネルギーに対応する純鉄の質 量吸収係数 ${ }^{10)} 0.339 \times 10^{2}\left[\mathrm{~cm}^{2} / \mathrm{g}\right]$ と融点直下での $\delta$ 鉄密度の 
文献值 ${ }^{11)} 7.25\left[\mathrm{~g} / \mathrm{cm}^{3}\right]$ から線吸収係数を求め, X線カメラ $2 \theta=23^{\circ}$ の条件および式 (2)よりX線侵入深さは入射角の 関数として Fig. 3 のように見積もられる。さらに $2 \theta-\theta$ の関 係を近似的に構築できれば，相率を準定量的に求めること も可能となる。散乱角の中心がおよそ $23^{\circ}$ となり $\theta$ は $\approx 10^{\circ}$

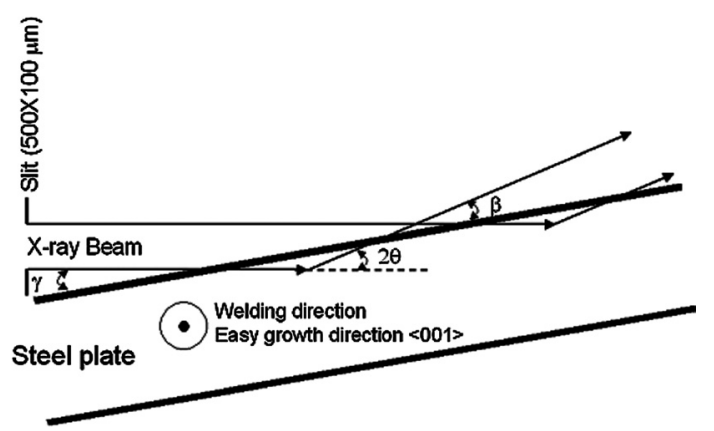

Fig. 2. Scattering geometry and penetration depth estimation for X-ray.

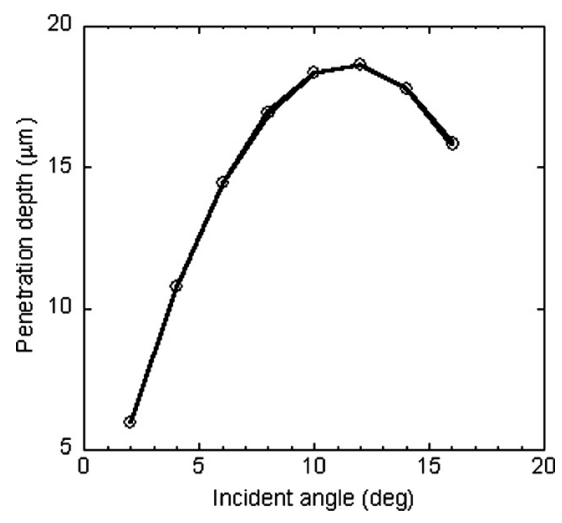

Fig. 3. Penetration depth of X-ray in $\delta$-ferrite as a function of incident angle in the X-ray energy of $18 \mathrm{keV}$.
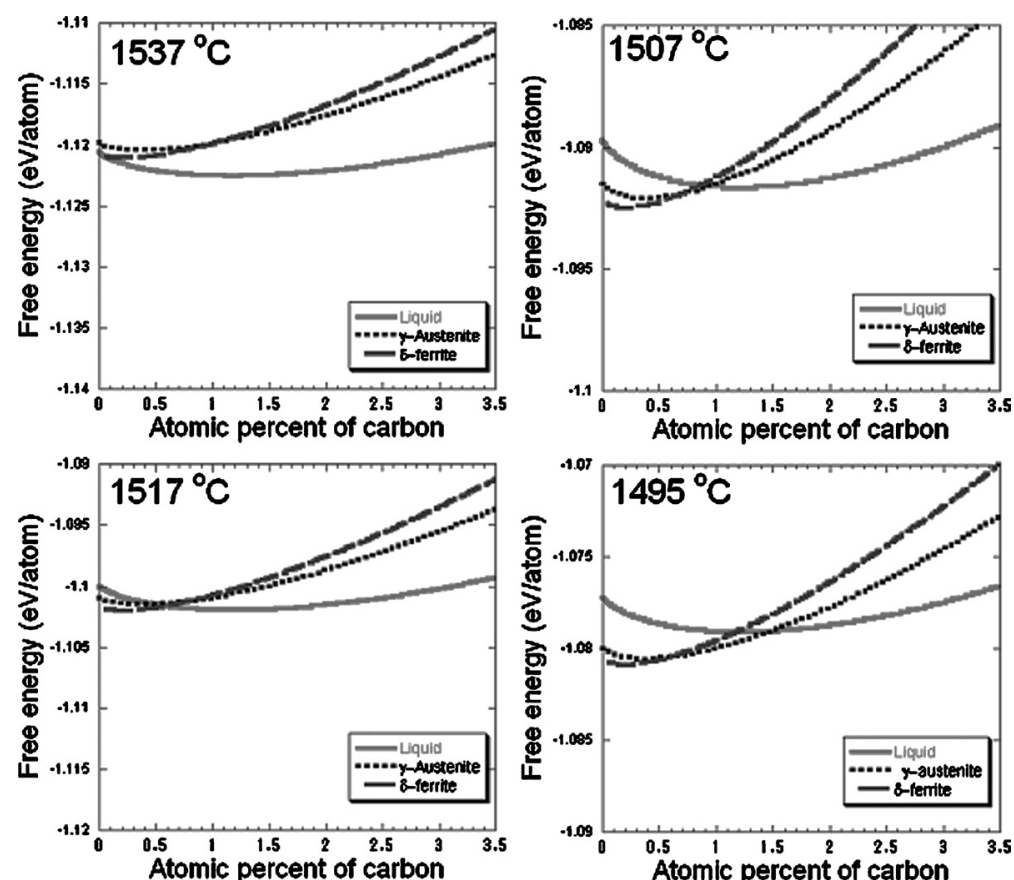

Fig. 4. Calculated free-energy in $\mathrm{Fe}-\mathrm{C}$ system by using sub-lattice model with Gustafson's parameter. ${ }^{11)}$
が望ましく，Fig. 3 より侵入深さも深い（溶接金属表層部 に溶接方向に成長するデンドライトの一本あたりの平均径 は約 $15 \mu \mathrm{m})$ 。以上のことを考虑して入射角 $10^{\circ}$ 選定し た。

\section{$3 \cdot 3$ 必要時間分解能}

鉄-炭素 2元系における副格子モデル ${ }^{12)}$ 基づいて液 相， $\delta$ フェライト相执よびオーステナイト相の自由エネル ギーを $1537 \sim 1495^{\circ} \mathrm{C}$ で計算した結果を Fig. 4 に示し，液相一 $\delta$ 相および液相 $-\gamma$ 相における共通接線組成を Fig. 5 に示 す。液相 $-\delta$ 相はたかだか $20^{\circ} \mathrm{C}$ 程度の範囲である。またそ の背面に示されるように, 溶接のような急冷プロセスにお いては凝固時の結晶成長速度, 結晶先端半径によっては, 凝固界面温度がオーステナイト相の方が高くなり, 液相一 $\gamma$ 相，つまり非平衡相の出現も予測される。

例えば，ティグ溶接プロセスの場合，およそ $210^{\circ} \mathrm{C} / \mathrm{s}$ 程 度 ${ }^{13)}$ の冷却速度が見積もられ, Fig. 5の領域は, 過冷が無 いと仮定した場合， $\delta$ 相が $20^{\circ} \mathrm{C}$ 程度の範囲なのでおよそ 0.1 秒程度の相変態現象であることがわかる。そのため,

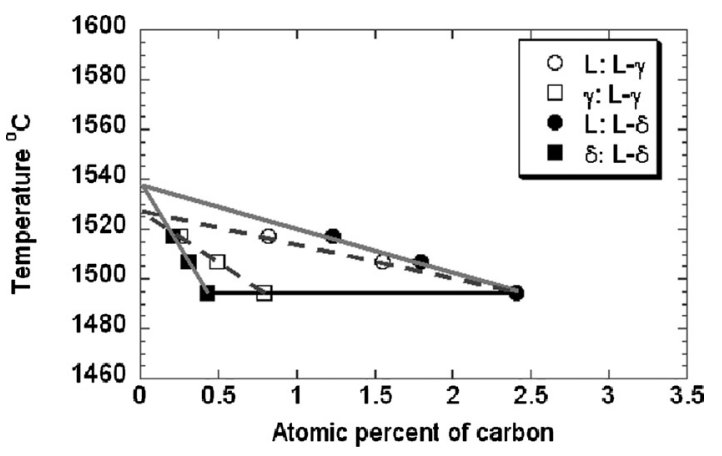

Fig. 5. Equilibrium (solid line) and non-equilibrium (dashed line) phase diagram in $\mathrm{Fe}-\mathrm{C}$ system. 

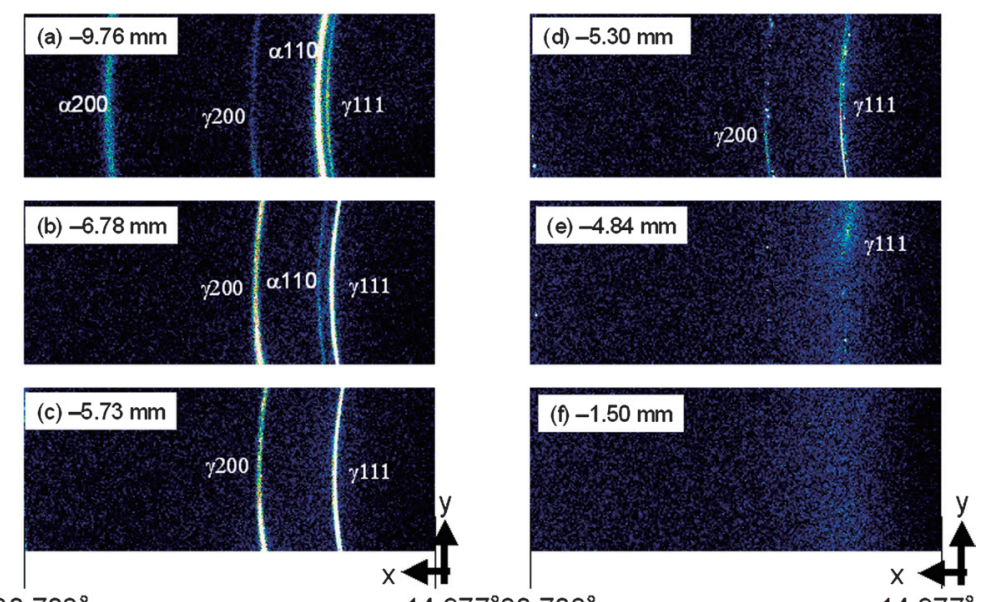

$30.703^{\circ}$

$14.977^{\circ} 30.703^{\circ}$

$14.977^{\circ}$

Fig. 6. Diffraction patterns for heating process of TIG welding for $13 \mathrm{Cr}-9 \mathrm{Ni}$ steel. The welding torch positions were from -9.76 $\mathrm{mm}$ to $-1.5 \mathrm{~mm}$.

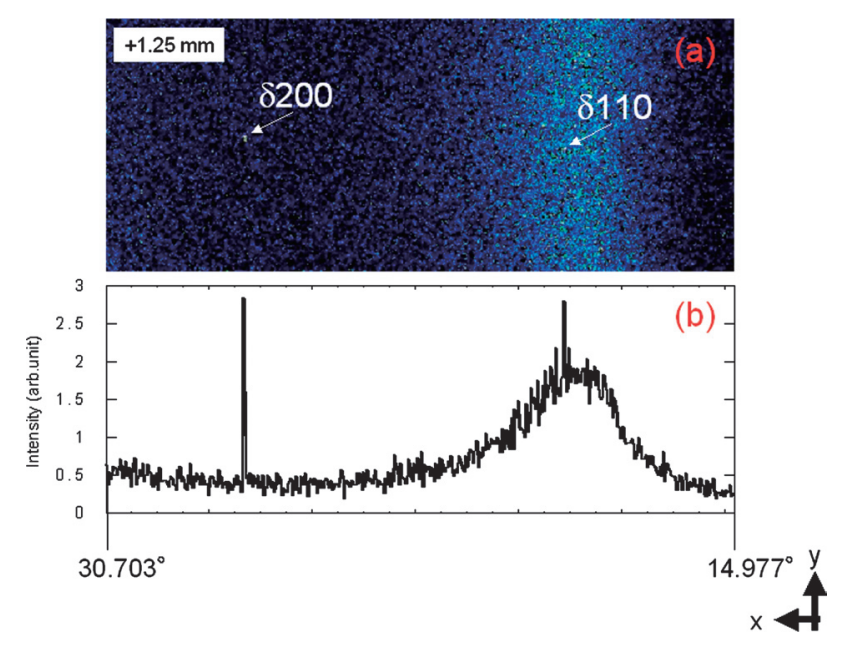

Fig. 7. Diffraction patterns for solidification process (primary phase) of TIG welding for $13 \mathrm{Cr}-9 \mathrm{Ni}$ steel. The welding torch position was $+1.25 \mathrm{~mm}$.

ティグ溶接時の溶接部組織変化を凝固過程から時系列で解 析するためには， $0.1 \mathrm{~s}$ 未満の時間分解能が必要となる。

\section{$3 \cdot 4 \quad 13 \mathrm{Cr}-9 \mathrm{Ni}$ 鋼溶接部の溶融・凝固過程}

観察例として，高強度鋼 $(0.018 \mathrm{C}-0.29 \mathrm{Si}-0.8 \mathrm{Mn}-9.05 \mathrm{Ni}-$ $12.95 \mathrm{Cr}-0.49 \mathrm{wt} \%$ Mo-bal.Fe) 定速ビードオンプレート溶接 時の溶接金属の溶融・凝固過程を時系列に観察した結果を 示す。Fig. 1に示すようにX線照射位置は固定であり， ティグ溶接トーチがその位置に近づけば加熱, 照射位置近 傍で溶融過程, 照射位置から溶接トーチが離れるにした がって凝固過程を時系列に観察することになる。そこで， 溶接ティグトーチが X線照射位置直上にある場合を $0 \mathrm{~mm}$ として, 回折パターンを示す。Fig. 6に溶接トーチ位置 $-9.76 \sim-1.5 \mathrm{~mm}$ に対応する加熱〜溶融過程での回折パ ターンを示す。観察時の時間分解能は 0.02 秒である。困中 $x-y$ はFig. 1 に示すカメラ方向に対応している。Fig. 6(a) は 溶接部が加熱される前の回折パターンに対応し，フェライ 卜相抢よびオーステナイト相から成る。溶接トーチがX線 照射部に近づき加熱されるに従い, Fig 6(b)に示すように
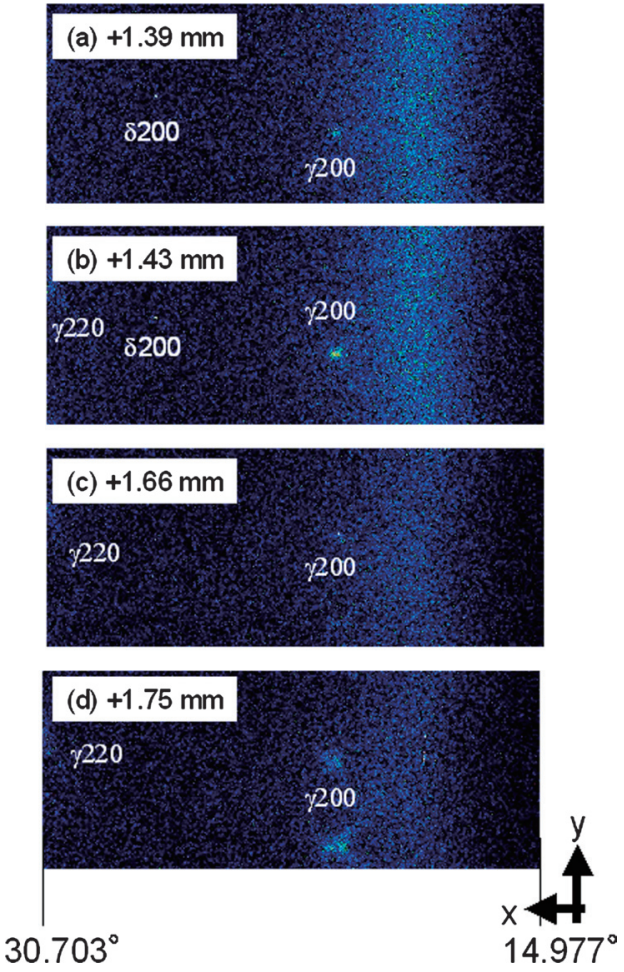

Fig. 8. Diffraction patterns for solidification process (peritectic reaction) of TIG welding for $13 \mathrm{Cr}-9 \mathrm{Ni}$ steel. The welding torch positions were from $+1.39 \mathrm{~mm}$ to $+1.75 \mathrm{~mm}$.

$\alpha$ 相の回折パターンの強度は弱くなり $\gamma$ 相の回折パターン 強度が増加, さらに各ピークが散乱角度の低角方向へ移動 している様子が観察できる。さらに溶接トーチが近づくに つれ, Fig. 6(d-e)のように $\gamma$ 相に対応するリングパターン が粗くなり, 結晶粒の粗大化及び溶融過程を表している。 Fig. 6(f)では, 回折パターンは消滅し, 完全に溶融した。

Fig. 7 にチグ溶接トーチがX線照射位置から+1.25 mm 離れたときの凝固過程に対応する回折パターンを示す。 Fig. 7(a)に示すようにスポット状の回折パターンとして， $\delta$ 相が検知された。スポットサイズが小さいが, Fig. 7(b)に 
$\phi$ 方向のピクセルを加算した $2 \theta$-強度図で示す。 $\delta 110$, 200 反射が明瞭に観察できる。また $\delta 110$ の回折パターンは 広くブロードしたパターンと重畳していることがわかり， このブロードしているパターンは液相の短範囲規則性に よって生じるハローパターンである。溶接においては, 凝 固過程に打ける液相中に生成する初相の結晶構造は偏析挙 動と関係があり，溶接欠陥を考虑する上で重要な情報であ る。本観察手法により，移動熱源中で直接的に同定する可 能性が示された。回折パターンがスポットになることは, 移動溶接熱源により強制的に熱束方向が決定され，一方向 凝固によりデンドライトが生成したためである。このよう な配向が生じても, 本計測システムでは二次元カメラの測 定範囲内で測定可能である。

アンジュレータビームを単色化した本計測システムの入 射ビームの平行性は極めて高い。しかしながらこれは，工 ワルド球で回折現象をべクトル的に考察した場合, 球の厚 さが非常に薄いこと（波長分散が小さいこと）に対応して いる。そのため，配向を示す溶接凝固組織を観察する場合 には観察に不利である。しかしながら高い平行性は高ピー ク強度の原因の一つとなっており高時間分解能観察という 点では望ましい特徴である。今後この点に関する検討が 必要であると考えている。

Fig. 8にティグ溶接トーチがX線照射位置から+1.39 $+1.75 \mathrm{~mm}$ 離れたときの凝固過程に対応する回折パターン を示す。Fig. 8(a)に示すように $\gamma$ 相が出現し，液相 $-\delta$ 相 $-\gamma$ 相による包晶反応に対応している。その後 $\delta$ 相の回折パ ターンはFig. 8(c) に示すように消滅し，八ローパターン強 度は弱くなった。Fig. 8(d)のように包晶反応後, $\gamma$ 単相と なった。

\section{4. 結論}

放射光を用いた溶接凝固・変態過程のその場観察新手法
（溶融凝固 in-situ相同定システム）についてまとめた。さ らに, 観察例として, $13 \mathrm{Cr}-9 \mathrm{Ni}$ 鋼溶接部の溶融・凝固過 程の回折パターンを時系列に示し, 溶接研究に打ける本計 測システムの有効性を示した。今後の課題は，最適波長分 散の探索, 溶接熱源・䨌囲気の制御, 相率の定量化および 正確な温度推定であると考えている。

共同研究者である住友金属総合技研の米村光治氏，小薄 孝裕氏, JASRIの佐藤真直氏, 豊川秀訓氏に感謝いたしま す。本研究は第 15 回鉄鋼研究助成の成果であり, ここに 謝意を表します。

\section{文献}

1 ) J.W.Elmer, J.Wong, M.Froba, P.A.Waide and E.M.Larson: Metall. Mater. Trans. A, 27 (1996), 775.

2 ) J.W.Elmer, J.Wong and T.Ressler: Metall. Trans. A, 32A (2001), 1175.

3 ) T.A.Palmer, J.W.Elmer and J.Wong: Sci. Technol. Weld Joining, 7 (2002), 159.

4 ) J.W.Elmer, J.Wong and T.Ressler: Scr. Mater, 43 (2000), 751.

5 ) S.S.Babu, J.W.Elmer, J.M.Vitek and S.A.David: Acta Mater, 50 (2002), 4763.

$6)$ A.T.Gorton, G.Bitsianes and T.L.Joseph: Trans. Metall. Soc. AIME, 233 (1965), 1519.

7 ) E.F.Eikenberry, Ch.Bronnimann, G.Hulsen, H.Toyokawa, R.Horisberger, B.Schmitt, C.Schulze-Briese and T.Tomizaki: Nucl. Instr. and Meth. A, 501 (2003), 260.

8 ) B.Schmitt, Ch.Bronnimann, E.F.Eikenberry, G.Hulsen, H.Toyokawa, R.Horisberger, F.Gozzo, B.Patterson, C.Schulze-Briese and T.Tomizaki: Nucl. Instr. and Meth. A, 518 (2004), 436.

9 ) B.E.Warren: X-ray Diffraction, Dover, (1990), 46.

10) S.Sasaki: KEK Report, 90 (1990), 1.

11) W.Kurz and D.J.Fisher: Fundamentals of Solidification, Trans Tech, (1984), 240.

12) P.Gustafson: Scand. J. Metall., 14 (1985), 259.

13) J.C.Ion, K.E.Eastering and M.F.Ashby: Acta Metall., 32 (1984), 1949. 